\title{
Growing season extended in Europe
}

$\mathrm{C}$ hanges in phenology (seasonal plant and animal activity driven by environmental factors) from year to year may be a sensitive and easily observable indicator of changes in the biosphere. We have analysed data from more than 30 years of observation in Europe, and found that spring events, such as leaf unfolding, have advanced by 6 days, whereas autumn events, such as leaf colouring, have been delayed by 4.8 days. This means that the average annual growing season has lengthened by 10.8 days since the early 1960s. These shifts can be attributed to changes in air temperature.

Forests in cool and temperate zones are adapted to the seasonal cycle, having a dormancy period during winter that is triggered mainly by seasonal variation in temperature and light. Seasonal phases can also be influenced by soil, water supply and biotic factors, including genes ${ }^{1,2}$. Plants can therefore be used as biological indicators of changing environmental conditions, with springtime phases being particularly sensitive to temperature.

We have been analysing ${ }^{3}$ observational data from the International Phenological Gardens (IPG), a Europe-wide network covering a large latitudinal (from Scandinavia at $69^{\circ} \mathrm{N}$ to Macedonia at $42^{\circ} \mathrm{N}$ ) and longitudinal (from Ireland at $10^{\circ} \mathrm{W}$ to Finland at $27^{\circ} \mathrm{E}$ ) range that has genetically identical clones of trees and shrubs (Fig. 1). The dates of observed phases, such as leaf unfolding, May shoot, flowering, leaf colouring and leaf fall, were recorded from 1959 to 1993.

We set out to apply a unified phenological model to the IPG network in order to simulate the consequences of climatic change. According to the model ${ }^{3}$, more than $70 \%$ of the interannual variability in

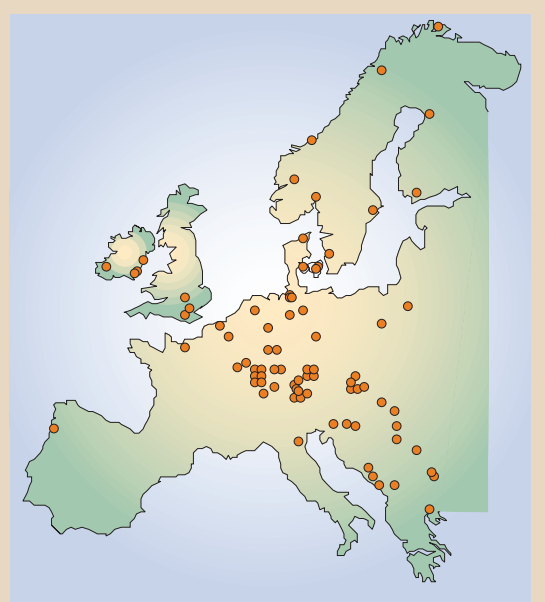

Figure 1 Sites of the International Phenological Gardens (IPG).

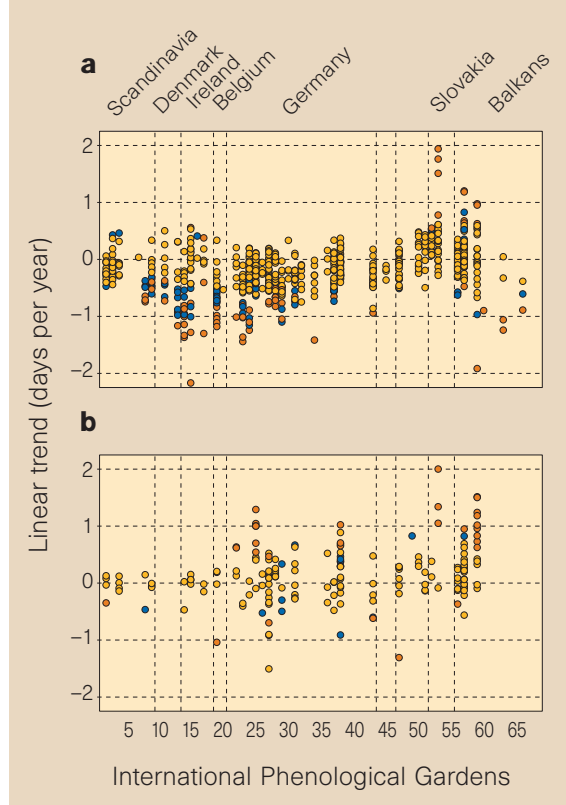

Figure 2 Linear trends of phenological phases. Data are for long observational series (20 years or more) during the 1959-93 period. Orange dots, significant at the $1 \%$ level; blue dots, significant at the $5 \%$ level; and yellow dots, not significant at the $5 \%$ level; $F$ test. a, Spring phases (including leaf unfolding, May shoot, flowering); b, autumn phases (including leaf colouring, leaf fall).

bud-break can be explained by daily temperatures; mean absolute errors in estimating phenological data ranged between 4 and 8 days. The model showed that the onset of spring events is sensitive to climatic change and will advance by up to six days per $1{ }^{\circ} \mathrm{C}$ increase in winter air temperature depending on the species, a figure similar to previous results ${ }^{4,5}$.

We also looked for trends that might reflect global warming, so, for all phenological records covering at least 20 years, we calculated linear trends and their significance according to F-test, trend/noise ratio and the Mann-Kendall trend test. Only a quarter of all trends are significant. Spring phases generally show a tendency for negative trends (Fig. 2a), indicating that spring is starting earlier in later years. Some of the Balkan stations, in contrast, show higher positive trends, indicating that spring is delayed, but this is probably the result of regional patterns of climate change. A positive (but less consistent) trend for the autumn phases (Fig. 2b) indicates that the beginning of autumn is gradually delayed over the years.

Averaging all 616 springtime data series reveals a negative trend of -0.20 days per year, equivalent to an advance of 6 days over 30 years. Analysis of the 178 autumn data series reveals a mean positive trend of +0.16 days per year, which would mean a delay of 4.8 days over 30 years. The growing season over this period has therefore lengthened by 10.8 days on average.

Other factors that could result in similar trends can be excluded. Only a few of the IPGs are situated in city areas where the urban heat island could influence these trends. In addition, the trends of spring phases are not an artefact of plant ageing because the increasing age of trees would be expected to delay the start of spring.

Our Europe-wide results are supported by regional studies, including a shift towards earlier flowering of the locust tree Robinia pseudoacacia in Hungary ${ }^{6}$ and the advance of spring and delay of autumn revealed by analysis of thermal seasons in Germany ${ }^{7}$.

The apparent increase of 10.8 days in the mean annual growing season in Europe is in accord with an analysis of satellite data from 1981 to 1991, which estimates a global advance of $8 \pm 3$ days for the beginning of the growing season and a prolongation by $4 \pm 2$ days of the declining phase ${ }^{8}$. Our data also confirm a reported ${ }^{9}$ advance in the seasonal cycle of about 7 days that was inferred from $\mathrm{CO}_{2}$ data taken between the 1960s and early 1990 s, with most of the effect occurring after 1980.

Our phenological modelling indicates that the changes are caused by a temperature increase, which is one of the effects of global warming. The lengthening of the growing season is likely to contribute to increased biomass formation, which is part of a global increase in biospheric activity ${ }^{8,9}$. This increase has resulted in accelerated tree growth across Europe, which has previously been attributed ${ }^{10}$ to fertilization by nitrogen compounds and $\mathrm{CO}_{2}$, but the effects of lengthening the growing season have yet to be quantified.

\section{Annette Menzel, Peter Fabian}

Department of Bioclimatology and Pollution

Research, University of Munich,

Faculty of Forest Science,

D-85354 Freising, Germany

e-mailmenzel@met.forst.uni-muenchen.de

1. Defila, C. Thesis, Univ. Zürich (1991).

2. Schnelle, F. Pflanzen-Phänologie (Geest \& Portig, Leipzig, 1955).

3. Menzel, A. Forstliche Forschungsberichte 164 (Münich, 1997)

4. Park-Ono, H. S., Kawamura, T. \& Yoshino, M. in Proc. 13th Int. Congr. Biometereology, Sept 12-18, 1993 (eds Maarouf, A. R. \& Barthakur, N. N.) 207-220 (Calgary, 1994).

5. Kramer, K. Plant Cell Environ. 17, 367-377 (1994)

6. Walkovszky, A. Int. J. Biometeorol. 41, 155-160 (1998).

Rapp, J. \& Schönwiese, C.-D. Meteorol. Z. 3, 91-94 (1994).

8. Myneni, R. B., Keeling, C. D., Tucker, C. J., Asrar, G. \& Nemani, R. R. Nature 386, 698-702 (1997).

9. Keeling, C. D., Chin, F. J. S. \& Whorf, T. P. Nature 382, 146-149 (1996).

10. Spiecker, H., Mielikäinen, K., Köhl, M. \& Skovsgaard, J. P. (eds) Growth Trends in European Forests: Studies from 12 Countries (Springer, Berlin, 1996). 